\title{
Professor Dorothy Hodgkin
}

In October 1964 the Daily Mail carried a headline 'Grandmother wins Nobel Prize'. Dorothy Hodgkin won it 'for her determination by $\mathrm{X}$-ray techniques of the structures of biologically important molecules'.

She used a physical method, X-ray crystallography, first developed by W. L. Bragg, to find the arrangements of the atoms in simple salts and minerals. She had the courage, skill, and sheer willpower to extend the method to compounds that were far more complex than anything attempted before. The most important of these were cholesterol, vitamin D, penicillin and vitamin $B$ r 2. Later she was most famous for her work on insulin, but this reached its climax only five years after she had won the prize.

In the early Forties, when Howard Florey and Ernest Chain had isolated penicillin from Alexander Fleming's mould, some of the best chemists in Britain and the United States tried to find its chemical constitution. They were taken aback when a handsome young woman, using not chemistry but $\mathrm{X}$-ray analysis, then still mistrusted as an upstart physical technique, had the face to tell them what it was. When Dorothy Hodgkin insisted that its core was a ring of three carbon atoms and a nitrogen which was believed to be too unstable to exist, one of the chemists, John Cornforth, exclaimed angrily: 'If that's the formula of penicillin, I'll give up chemistry and grow mushrooms'. Fortunately he swallowed his words and won the Chemistry Prize himself 30 years later. Hodgkin's formula proved right and was the starting-point for the synthesis of chemically modified penicillins that have saved many lives.

Pernicious anaemia used to be deadly until the early Thirties when it was discovered that it could be kept in check by liver extracts. In 1948 the active principle, vitamin $B_{12}$, was isolated from liver in crystalline form, and chemists began to wonder what its formula was. The first X-ray diffraction pictures showed that the vitamin contained over a thousand atoms, compared to penicillin's 39 ; it took Hodgkin and an army of helpers eight years to solve its structure. Like penicillin, vitamin B 12 showed chemical features not encountered before, such as a strange ring of nitrogens and carbon atoms surrounding its central cobalt atom and a novel kind of bond from the cobalt atom to the carbon atoms of a sugar ring that provided the clue to the vitamin's biological function. The Nobel Prize was awarded to Hodgkin not just for determining the structures of several vitally important compounds, but also for extending the bounds of chemistry itself.

In 1935 Dorothy Crowfoot, as she then was, put a crystal of insulin in front of 
an X-ray beam and placed a photographic film behind it. That night, when she developed the film, she saw minute, regularly arranged spots forming a diffraction pattern that held out the prospect of solving insulin's structure. Later that night she wandered around the streets of Oxford, madly excited that she might be the first to determine the structure of a protein, but next morning she woke with a start : could she be sure that her crystals really were insulin rather than some trivial salt? She rushed back to the lab before breakfast. A simple spot test on a microscope showed that her crystals took up a stain characteristic for protein, which revived her hopes. She never imagined that it would take her 34 years to solve that complex structure, nor that once solved it would have practical applications. It has recently enabled genetic engineers to change the chemistry of insulin in order to improve its benefits for diabetics.

Dorothy Hodgkin's father, J. W. Crowfoot, was Education Officer in Khartoum and an archaeologist; her mother too was an archaeologist, with a particular interest in the history of weaving. When Dorothy was a child, they lived next door to the Sudan Government Chemist, Dr. A. F. Joseph. It was 'Uncle Joseph"'s early encouragement that largely excited her interest in science. Later he introduced her to the Cambridge Professor of Physical Chemistry, T. Martin Lowry, who advised her to work with J. D. Bernal.

It was when Dorothy Crowfoot was 24 and working in Cambridge with Bernal on crystals of another protein, the digestive enzyme pepsin, that Bernal made his crucial discovery of their rich X-ray diffraction patterns. But, on the day that he did, her parents had taken her to London to consult a specialist about persistent pains in her hands. He diagnosed the onset of the rheumatoid arthritis that was to cripple her hands and feet, but never slowed her determined pursuit of science.

At Oxford, Dorothy Hodgkin used to labour on the structure of life in a cryptlike room tucked away in a corner of Ruskin's Cathedral of Science, the Oxford Museum. Her Gothic window was high above, as in a monk's cell, and beneath it was a gallery reachable only by a ladder. Up there she would mount her crystals for X-ray analysis, and descend precariously, clutching her treasure with one hand and balancing herself on the ladder with the other. For all its gloomy setting, Hodgkin's lab was a jolly place. As Chemistry Tutor at Somerville she always had girls doing crystal structures for their fourth year and two or three research students of either sex working for their $\mathrm{Ph}$.D.s. They were a cheerful lot, not just because they were young, but because her gentle and affectionate guidance led most of them on to interesting results. Her best-known pupil, however, made her name in a career other than chemistry: Margaret Roberts, later Margaret Thatcher, worked as a fourth-year student on X-ray crystallography in Dorothy Hodgkin's laboratory. They always maintained a great affection for each other, despite their political differences.

In 1937 Dorothy had married the historian Thomas Hodgkin. They had three children and remained a devoted couple until Thomas's death in I982. Some women intellectuals regard their children as distracting impediments to their careers, but Dorothy radiated motherly warmth even while doing scientific work. Concentration came to her so easily that she could give all her attention to a child's 
chatter at one moment and switch to complex calculations the next. The Hodgkin's home was chaotic, cheerful, welcoming and hospitable to visitors, including many from the Third World.

'There are certain letters which I dread to open,' she once told me, 'and when I saw one from Buckingham Palace I left it sealed, fearing that they wanted to make me Dame Dorothy.' It would have made her feel like a femme formidable, which she so happily was not. She was relieved to find that the Queen offered her the Order of Merit, a much greater honour.

She pursued her crystallographic studies, not for the sake of honours, but because this was what she liked to do. There was magic about her person. She had no enemies, not even among those whose scientific theories she demolished or whose political views she opposed. Just as her $\mathrm{X}$-ray cameras bared the intrinsic beauty beneath the rough surface of things, so the warmth and gentleness of her approach to people uncovered in everyone, even the most hardened scientific crook, some hidden kernel of goodness. She was once asked in a BBC radio interview whether she felt handicapped in her career by being a woman. 'As a matter of fact,' she replied gently, 'men were always particularly nice and helpful to me because I was a woman.' At scientific meetings she would seem lost in a dream, until she suddenly came out with some penetrating remark, usually made in a diffident tone of voice, and followed by a little laugh, as if wanting to excuse herself for having put everyone else to shame.

She shared her husband's faith in the socialist paradise, no matter whether this was in the Soviet Union, China or Vietnam, and tended to close her eyes to the evils of the Communist dictatorships. Her high standing in the Soviet scientific community was recognised in 1982 by the award of the Lomonosov Gold Medal. In 1987 she was awarded the Lenin Peace Prize, in part no doubt for her championing of the Soviet cause, but also for her efforts to ease tension between East and West as President of the 'Pugwash' conferences on Science and World Affairs.

In 1955, the first of these conferences was stimulated by the Einstein-Russell Manifesto that drew attention to the mortal danger of thermonuclear war. They have since been held annually and have brought together scientists from all countries, meeting as individuals rather than representatives of governments and seeking co-operative solutions to disarmament and the reduction of international tension. Dorothy Hodgkin was made President in 1975. In the face of diametrically opposed views often angrily expressed by scientists from East and West or North and South, a few gentle thoughtful words in her soft voice cooled tempers and forestalled crises. She cared deeply for the Arab cause in the Middle East, for the poorer African countries, for China and Vietnam, and in times of tension she helped to keep open scientific dialogue between them and the West.

In 1970 Hodgkin was elected Chancellor of Bristol University, an office to which she brought a breath of fresh air. She attended meetings regularly and often acted as the university's conscience, taking an interest in individuals, particularly if she thought they had been hard done by. She was the first chancellor of the university always to visit the Students' Union and to have lunch with its officers, 


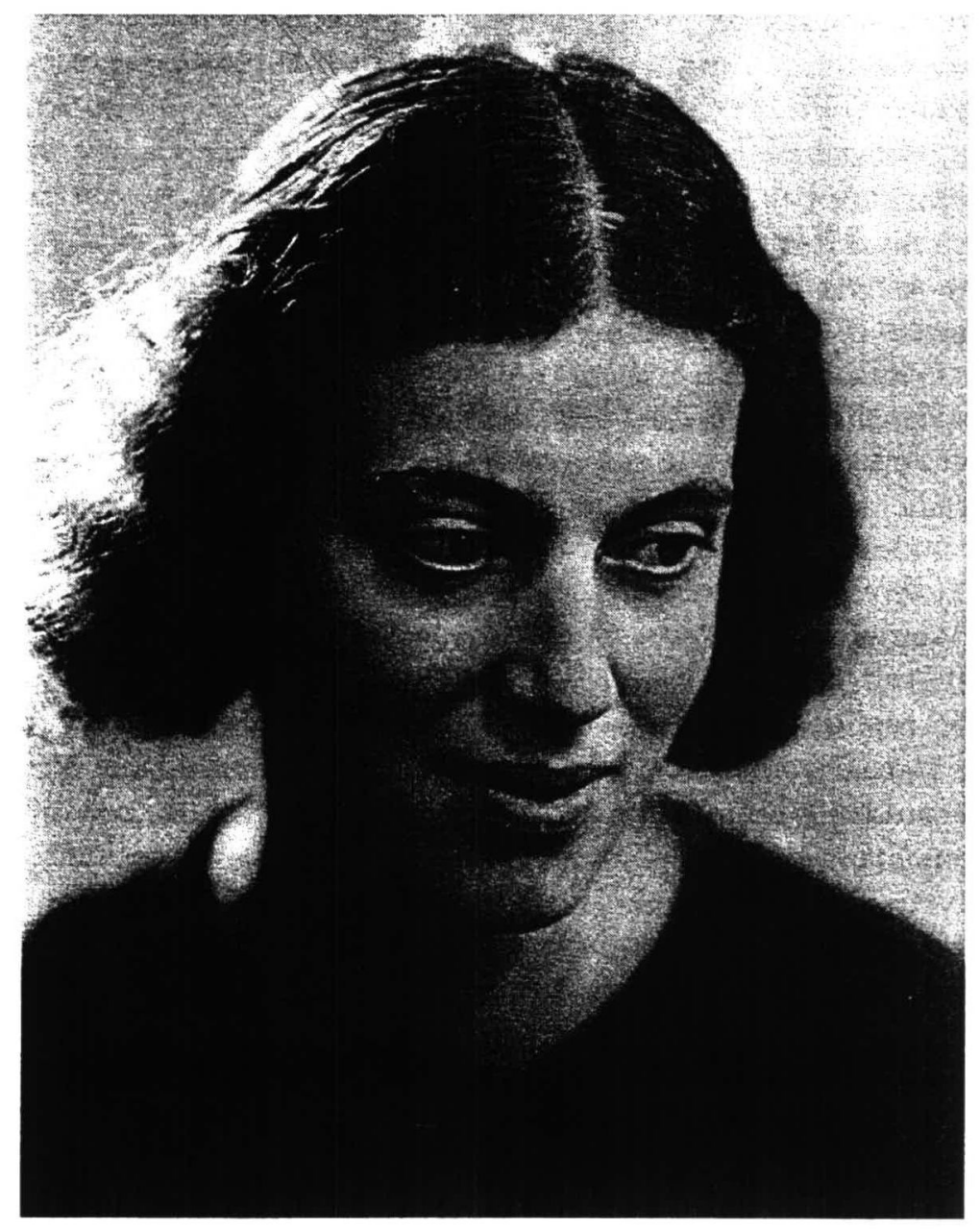

Hodgkin in 1937 , the year she married

Photograph: Ramsey and Muspratt

By courtesy of the National Portrait Gallery, London

and she took a keen interest in the research of her crystallographic colleagues. She supported the establishment of a Hodgkin Scholarship for a student from the Third World and of Hodgkin House to accommodate overseas students, both named after her late husband, a specialist in African studies.

Dorothy Hodgkin's uncanny knack of solving difficult structures came from a combination of manual skill, mathematical ability and profound knowledge of crystallography and chemistry. It often led her and her alone to recognise what the initially blurred maps emerging from $\mathrm{X}$-ray analysis were trying to tell. She will be remembered as a great chemist, a saintly, gentle and tolerant lover of people and a devoted protagonist of peace.

Max Perutz

Reproduced by permission from The Independent, Obituaries, I August 1994. 


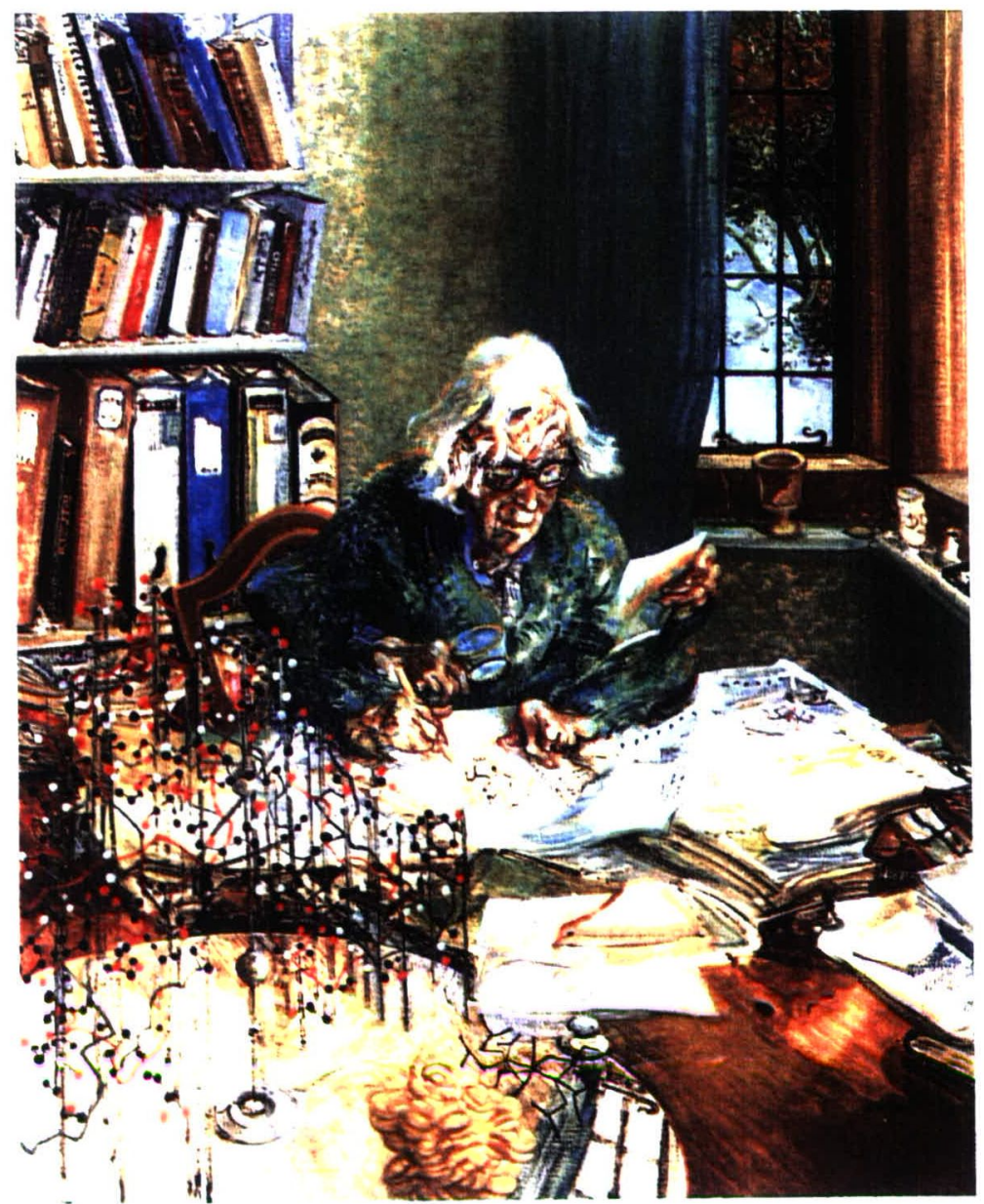

Magic about her person: a portrait of Hodgkin by Maggi Hambling, 1985 By courtesy of the National Portrait Gallery, London

Dorothy Mary Crowfoot, chemist: born Cairo I2 May Igro; Fellow, Somerville College, Oxford I936-77; FRS I947; Royal Society Wolfson Research Professor, Oxford University I960-77 (Emeritus); Nobel Prize for Chemistry I964; OM 1965; Chancellor, Bristol University 1970-88; Fellow, Wolfson College, Oxford 1977-82; married 1937 Thomas Hodgkin (died I982; two sons, one daughter); died Shipston-on-Stour, Warwickshire 29 fuly 1994. 